\title{
An empowerment programme to support children in child headed households in resource- poor communities in Soshanguve, South Africa: phase 2 of an intervention study
}

\author{
Julia E Ibebuike ${ }^{1 *}$, Corrien van Belkum², Todd MM Maja ${ }^{1}$ \\ From 2nd International Science Symposium on HIV and Infectious Diseases (HIV SCIENCE 2014) \\ Chennai, India. 30 January - 1 February 2014
}

\section{Background}

South Africa has been noted to have the fastest growing rate of people living with HIV/AIDS. This has led to an alarming increase in the number of children orphaned by AIDS and the attendant care of the orphaned children by their siblings leading to the formation of child headed households (CHHs). The study was conducted in two phases. Phase 1 identified CHHs in a resource poor community in South Africa, their lived experiences, their needs and the resource poor communities' knowledge and perceptions about these households. Phase 2 of the study aimed at developing, implementing and evaluating an empowerment programme to support the children in $\mathrm{CHHs}$ in the resource poor communities.

\section{Methods}

The design for the study was a qualitative contextual intervention study and targeted children in $\mathrm{CHHs}$ who participated in Phase 1 of the study. Data was collected using in depth interviews, and data analysis was by open coding using Tesch's approach.

\section{Results}

The study findings revealed the following, (1) structure for developing an empowerment programme to support children in $\mathrm{CHHs}$ in resource poor communities, (2) framework for empowerment programme to support children in CHHs, (3) summary of the implementation of the framework for an empowerment programme to

\footnotetext{
* Correspondence: juliaibebuike@yahoo.com

${ }^{1}$ Adelaide Tambo School of Nursing Science, Tshwane University of

Technology, Pretoria, South Africa

Full list of author information is available at the end of the article
}

support children in $\mathrm{CHHs}$, (4) evaluation of the implementation and outcome of the empowerment programme.

\section{Conclusion}

An empowerment programme was developed, effectively implemented and the children's needs supported.

\section{Authors' details}

'Adelaide Tambo School of Nursing Science, Tshwane University of Technology, Pretoria, South Africa. ${ }^{2}$ College of Nursing, King Saud bin Abdulazis University for Health Sciences, Riyadh, Saudi Arabia.

\section{Published: 27 May 2014}

doi:10.1186/1471-2334-14-S3-O29

Cite this article as: Ibebuike et al:: An empowerment programme to support children in child headed households in resource-poor communities in Soshanguve, South Africa: phase 2 of an intervention study. BMC Infectious Diseases 2014 14(Suppl 3):O29.

Submit your next manuscript to BioMed Central and take full advantage of:

- Convenient online submission

- Thorough peer review

- No space constraints or color figure charges

- Immediate publication on acceptance

- Inclusion in PubMed, CAS, Scopus and Google Scholar

- Research which is freely available for redistribution

Submit your manuscript at www.biomedcentral.com/submit 